\title{
Effect of combined washing with heat and microbubbles water on the quality of fresh-cut lettuce
}

\author{
Hyo Jin Kim ${ }^{1}$, Kyung Min Park ${ }^{2,3}$, Mooncheol Jeong ${ }^{3}$, \\ Kee Jai Park ${ }^{3}$, Minseon $\mathrm{Koo}^{2,4 *}$ \\ ${ }^{1}$ Technical Service Center, Korea Food Research Institute, Wanju 55365, Korea \\ ${ }^{2}$ Department of Food Biotechnology, Korea University of Science \& Technology, Daejoen 34113, Korea \\ ${ }^{3}$ Research Group of Consumer Safety, Korea Food Research Institute, Wanju 55365, Korea \\ ${ }^{4}$ Food Analysis Center, Korea Food Research Institute, Wanju 55365, Korea
}

\section{열수 마이크로버블 병용 세척이 절단 양상추의 품질에 미치는 영향}

\author{
김효진 ${ }^{1} \cdot$ 박경민 $^{2,3} \cdot$ 정문철 $^{3} \cdot$ 박기재 $^{3} \cdot$ 구민선 $^{2,4 *}$ \\ ${ }^{1}$ 한국식품연구원 기술지원센터, ${ }^{2}$ 한국과학기술연합대학원대학교 식품생명공학과, \\ ${ }^{3}$ 한국식품연구원 소비안전연구단, ${ }^{4}$ 한국식품연구원 식품분석센터
}

\begin{abstract}
The effects of different washing techniques, including the combined use of heated water and microbubbles water, on fresh-cut lettuce leaves (Lactuca sative var, capitata) were examined. The outer leaves were removed from the lettuce and cut into squares with dimensions of approximately 1-2 cm. The lettuce leaf samples were then washed with either tap water (Tap), microbubbles water (MB, Contains $70 \%$ or more of microbubbles with a diameter of $10 \mu \mathrm{m}$ or less), heated water $\left(\mathrm{HWT}, 40^{\circ} \mathrm{C}, 45^{\circ} \mathrm{C}\right.$ or $\left.50^{\circ} \mathrm{C}\right)$, or heated microbubbles water $\left(\mathrm{HWT}+\mathrm{MB}, 40^{\circ} \mathrm{C}\right.$, $45^{\circ} \mathrm{C}$ or $50^{\circ} \mathrm{C}$ ) for $1 \mathrm{~min}$. After washing, the microbiological properties (i.e., total viable bacteria, coliform and fungi) and quality of the samples were measured. The total viable bacteria level of the HWT-50 ${ }^{\circ} \mathrm{C}$ sample was $<1 \log \mathrm{CFU} / \mathrm{g}$, representing the most effective washing technique, although the freshness decreased rapidly during storage. In addition, $\mathrm{HWT}+\mathrm{MB}-40^{\circ} \mathrm{C}$ treatment was less effective in reducing the microbiological levels, although the decay rate was maintained at $0 \%$ for the initial $2 \mathrm{~d}$ of storage, and showed the lowest value of $11 \%$ after $6 \mathrm{~d}$. Furthermore, the decay rate for the sample treated with $\mathrm{MB}$ was $<30 \%$ after $10 \mathrm{~d}$, and a similar result was obtained for the $\mathrm{HWT}+\mathrm{MB}-40^{\circ} \mathrm{C}$ sample. It was apparent that a combined heat and microbubbles treatment, and in particular at a temperature of $40^{\circ} \mathrm{C}$, was effective for maintaining the freshness and quality of fresh-cut lettuce during storage.
\end{abstract}

Key words : microbubble, washing treatments, fresh-cut lettuce, microorganism, freshness

서 론

신선편이 식품이란 과일, 채소 등의 농산물을 박피, 세 척, 절단하여 물리적으로 변형시켜 포장한 제품으로, 신선 함과 간편성을 가진 가공식품이다(Huxsoll과 Bolin, 1989;
Gemma 등, 2010). 국내에서는 간편성을 중시하는 현대인 들의 소비패턴과 단체급식시장, 외식산업의 급성장으로 인하여 수요가 크게 증가하였다(Ahvenainen, 1996). 증가 하는 신선편이 식품의 수요를 충족시키기 위해서는 제품 의 선도 유지 기간이 중요하며, 이는 제품생산 과정 중의

*Corresponding author. E-mail : minsk@kfri.re.kr, Phone : +82-63-219-9161, Fax : +82-63-219-9876

Received 18 October 2019; Revised 27 November 2019; Accepted 16 December 2019.

Copyright (c) The Korean Society of Food Preservation.

This is an Open Access article distributed under the terms of the Creative Commons Attribution Non-Commercial License (http://creativecommons.org/licenses/by-nc/4.0) which permits unrestricted non-commercial use, distribution, and reproduction in any medium, provided the original work is properly cited. 
품질관리에 따라 크게 좌우된다. 신선편이 식품의 품질은 제품 생산 과정에서 미생물에 의한 오염이나 절단 과정 중 발생하는 조직연화, 갈변 등에 의해 급격하게 변화하며, 초기 품질상태는 세척을 통한 미생물 제어에 의해 우선적 으로 결정된다. 세척 공정은 원료의 이물질을 제거하고, 초기 미생물 오염을 감소 및 억제하기 위하여 이루어지며, 주로 염소수로 세척하지만, 열수, 오존수, 전해수, 마이크 로버블수 등 다양한 세척수를 이용한다. 현재 신선편이 식품의 세척수에 관해서는 염소수와 젖산칼슘을 이용한 양상추와 당근의 세척효과(Martin-Diana 등, 2005), 양상추 세척수로서 염소수의 화학적 안전성과 미생물 저감효과 (Van Haute 등, 2013), 전해수와 오존수로 세척한 고수의 품질 특성(Wang 등, 2004), 전기분해수의 세척 살균 및 미생물 감소 효과(Izumi, 1999; Koseki 등, 2001; Lee 등, 2011) 등 다양한 연구가 진행되어있다. 다양한 세척수 중 세척공정에서 가장 많이 사용되는 염소수는 미생물에 의 한 오염을 효과적으로 억제한다고 알려져 있으나, 자극적 이며, 염소 부산물 형성에 대한 위험성이 있다(Li 등, 2001; Allende과 Artes, 2003). 염소수에 대한 잠재적 위험성 때문 에 독일, 네덜란드, 스위스와 같은 일부 국가에서는 즉석섭 취식품에서의 염소수 사용을 금지하고 있으며(Ricoa 등, 2007), 염소수를 대체할 수 있는 친환경적인 세척수의 개 발이 요구되고 있다. 친환경적인 세척수로 대두되고 있는 마이크로버블수는 직경이 10-50 $\mu \mathrm{m}$ 인 작은 마이크로버 블을 이용한 것으로, 마이크로버블은 물속에서 소량의 reactive oxygen species(ROS)를 생성하며, 그 중 $\mathrm{OH}$ radical 에 의해 살균세정 효과가 있다고 알려져 있다(Liu 등, 2016). 현재, 마이크로버블수를 이용한 세척에 관한 연구 는 마이크로버블에 의한 상추의 미생물 저감 효과(Lee 등, 2009), 오존마이크로버블을 이용한 잎채소 표면의 박테리 아 감소 효과(Inatsu 등, 2011), 다양한 채소에서의 마이크 로버블수의 세척살균효과(Lee 등, 2011) 등이 진행되어 있지만, 양상추에 대한 연구는 다른 작물들에 비해 많이 연구되어 있지 않으며, 특히 갈변이 더 빠르게 진행되는 절단 양상추에 대한 마이크로버블 세척에 관한 연구는 거의 진행되지 않았다.

본 연구에서는 신선편이 식품 중 수요가 가장 많은 절단 양상추를 이용하여 저장 기간 동안 좋은 품질을 유지할 수 있는 친환경적인 세척 조건을 탐색하고자, 저장 중의 마이크로버블 처리구와 열수 마이크로버블 병용 처리구 의 품질변화를 확인하였다.

\section{재료 및 방법}

\section{실험재료}

본 실험에 사용한 양상추(Lactuca sativa var. capitata)는
2018년 3월 서울 가락시장에서 구입하여 외관과 모양이 균일한 것을 선별하여 사용하였다.

\section{세척 및 저장}

선별된 양상추는 겉잎을 제거하고, 추가로 2 잎 가량 떼 어낸 후 약 1-2 $\mathrm{cm}$ 의 정사각형 모양으로 절단하였다. 양상추의 심과 노란 잎은 세척에 사용하지 않았다. 세척 처리구는 대조구로 무세척구(NT)를 이용하였고, 일반 수 도수(Tap), 마이크로버블수(MB), $40^{\circ} \mathrm{C}, 45^{\circ} \mathrm{C}, 50^{\circ} \mathrm{C}$ 의 열수 (HWT), $40^{\circ} \mathrm{C}, 45^{\circ} \mathrm{C}, 50^{\circ} \mathrm{C}$ 열수와 마이크로버블 혼합수 $(\mathrm{MWT}+\mathrm{MB})$ 로 각각 1 분씩 세척하였다. 세척에 사용된 수 조는 약 $52 \mathrm{~L}$ 의 수조이며, 마이크로버블 발생기는 직경이 $10 \mu \mathrm{m}$ 이하인 마이크로버블이 $70 \%$ 이상을 차지하는 자체 개발 기기를 사용하였고, 이때의 용존산소는 8.71-8.96 $\mathrm{mg} / \mathrm{L}$ 였다. 실험에 사용한 절단 양상추의 양은 절단 양상추 세척 업체에서 적용할 수 있는 결과를 얻고자 각 처리구별 약 $10 \mathrm{~kg}$ 씩 사용하였다. 1회 세척시 투입된 절단 양상추의 양은 약 $10 \mathrm{~kg}$ 이었으며, 세척수는 세척시마다 교환하였고, 1 회 사용된 세척수 용량은 약 $50 \mathrm{~L}$ 이었다. 세척 후 야채탈수 기(T30-98B, Ecowell, Weihai, China)를 이용하여 약 30초간 탈수한 후 멸균거즈를 이용하여 표면물기를 제거하였다. 탈수된 절단 양상추는 현 시중 포장방법에 따라 두께가 $30.1 \pm 0.7 \mu \mathrm{m}$ 의 $\mathrm{OPP}$ film $(30 \times 20 \mathrm{~cm})$ 에 약 $100 \mathrm{~g}$ 씩 넣어 포장 한 후 열접합하였다. 시료는 $10 \pm 1^{\circ} \mathrm{C}$ 의 항온저장고에 저장 하면서 $2,6,8,10$ 일에 채취하여 품질의 변화를 분석하였다.

\section{미생물학적 품질평가}

절단 양상추의 미생물학적 품질평가는 식품공전법에 따라 일반세균, 진균류, 대장균군을 분석하였다(KFDA, 2017). 무작위적으로 $25 \mathrm{~g}$ 의 절단 양상추를 채취하여 225 $\mathrm{mL}$ 의 $0.85 \%$ 멸균 생리식염수를 가한 후 균질기(Stomacher ${ }^{\circledR}$ 400 circulator, Seward, Inc., London, England)를 이용하여 $230 \mathrm{rpm}$ 에서 2분간 균질화하였다. 균질화한 시료는 단계 별로 희석하여 희석액 $1 \mathrm{~mL}$ 씩 각각의 배지에 도말하여 계수하였다. 일반세균은 일반세균 측정용 건조배지 $\left(3 \mathrm{M}^{\mathrm{TM}}\right.$ Petrifilm ${ }^{\mathrm{TM}}$ Aerobic Count Plate)을 이용하였으며, $37^{\circ} \mathrm{C}$ 에서 48시간 배양 후 생성된 붉은색 집락을 계수하였다. 진균류 는 Cho 등(2015), Park 등(2016)이 언급한 건조필름법으로 분석하였으며, 진균류 측정용 건조배지 $\left(3 \mathrm{M}^{\mathrm{TM}}\right.$ Petrifilm ${ }^{\mathrm{TM}}$ Yeast and Mold Count Plates)를 이용하여 $30^{\circ} \mathrm{C}$ 에서 72 시간 배양한 후 생성된 녹색 집락 또는 여러 균체의 집락을 계수 하였다. 대장균군은 대장균군 측정용 건조배지(Sanitakun Coliform/E.coli, JNC Corporation, Tokyo, Japan)를 이용하 여, $37^{\circ} \mathrm{C}$ 에서 24 시간 배양하여 청녹색 집락을 계수하였다. 계수한 집락수에 희석배수를 곱하여 $\log \mathrm{CFU} / \mathrm{g}$ (colony forming unit/g)으로 나타내었다. 실험은 3반복 이상 수행하 
였으며, 평균표준편차로 나타내었다.

\section{부패율 측정}

조직의 연화로 인해 불투명하게 변화하여 짓무른 부분 또는 갈변된 부분이 한 개체의 $1 / 3$ 이상인 경우 부패된 것으로 간주하였으며, 부패율은 부패 개체수의 무게를 시 료 전체 무게에 대한 백분율로 나타내었다.

\section{통계처리}

수행한 실험의 결과는 SPSS Statistics 17(IBM Co., Armonk, NY, USA)를 이용하여, Duncan's multiple range test 를 실시하여 평균값 간의 유의성 검정을 하였다 $(\mathrm{p}<0.05)$.

\section{결과 및 고찰}

\section{세척수 종류에 따른 절단 양상추의 일반세균 변화}

절단 양상추 세척에 사용한 세척수 종류에 따른 일반세 균의 변화는 Table 1 과 같다. 일반적으로 과일 및 채소류의 일반세균수는 약 4-7 $\log \mathrm{CFU} / \mathrm{g}$ 으로 알려져 있으며 (Lamikanra, 1981), 대조구인 무세척구(NT)의 일반세균수 는 3.2 $\pm .7 \log \mathrm{CFU} / \mathrm{g}$ 으로 나타나, 문헌보다 낮게 나타났다. 이는 현재 신선편이 업체에서 절단 양상추를 생산하는 방 식과 같게 다량의 양상추 떡잎을 제거한 후 깨끗한 속잎을 사용하여 오염도가 낮은 것으로 판단된다. Park(2013)에 따르면, 초기 일반세균수가 $3 \log \mathrm{CFU} / \mathrm{g}$ 이하인 경우 다양 한 항균소재에 의한 감소효과를 기대하기 어렵다고 보고

Table 1. Changes in total viable bacterial counts of sliced lettuce washed with various washing conditions

(Unit: $\log \mathrm{CFU} / \mathrm{g}$ )

\begin{tabular}{ccc}
\hline \multicolumn{2}{c}{ Treatment $^{1)}$} & Total Bacterial \\
\hline NT & & $3.2 \pm 0.7^{2) \mathrm{bc} 3)}$ \\
Tap & & $4.5 \pm 0.1^{\mathrm{d}}$ \\
& $\mathrm{MB}$ & $3.8 \pm 0.1^{\mathrm{c}}$ \\
\hline & & $3.4 \pm 0.1^{\mathrm{b}}$ \\
$\mathrm{HWT}$ & $40^{\circ} \mathrm{C}$ & $4.5 \pm 0.1^{\mathrm{d}}$ \\
& $45^{\circ} \mathrm{C}$ & $0.0 \pm 0.0^{\mathrm{a}}$ \\
\hline & $50^{\circ} \mathrm{C}$ & $3.8 \pm 0.0^{\mathrm{c}}$ \\
$\mathrm{HWT}+\mathrm{MB}$ & $40^{\circ} \mathrm{C}$ & $4.4 \pm 0.1^{\mathrm{d}}$ \\
& $45^{\circ} \mathrm{C}$ & $4.8 \pm 0.2^{\mathrm{e}}$ \\
\hline
\end{tabular}

${ }^{1)} \mathrm{NT}$, not treatment; Tap, tap water; MB, microbubble water; HWT, hot water; $\mathrm{HWT}+\mathrm{MB}$, microbubble and hot water; Washing time = $1 \mathrm{~min}$.

${ }^{2)}$ Value are mean \pm SD $(n=3)$.

${ }^{3)}$ Means with different letters are significantly different $(\mathrm{p}<0.05)$ by Duncan's multiple range test.
하였다. 본 연구에서 사용한 양상추는 초기 일반세균수가 약 $3.2 \log \mathrm{CFU} / \mathrm{g}$ 으로, 초기 미생물학적 품질이 우수하게 나타났다. 초기 미생물학적 품질이 우수하여 세척 직후 처리 조건에 따른 미생물 저감 효과가 크게 나타나지는 않았다. 마이크로버블 세척구(MB)의 일반세균수는 $3.8 \pm 0.1 \mathrm{log}$ $\mathrm{CFU} / \mathrm{g}$ 으로, $4.5 \pm 0.1 \log \mathrm{CFU} / \mathrm{g}$ 인 수도수 세척구(Tap)에 비 해 일반세균수가 유의적으로 감소하였다. Lee 등(2011)은 일부 채소에서 마이크로버블수 세척구가 수도수 세척구보 다 일반세균수 저감에 효과적이라고 보고하였고, 슬라이 스 더덕의 경우에도 마이크로버블 세척구가 일반버블 세 척구보다 일반세균수를 $0.6 \log \mathrm{CFU} / \mathrm{g}$ 가량 저감시킨다고 알려져 있다(Choi 등, 2013). 열수 세척구(HWT)는 수도수 세척구(Tap)보다 일반세균수 저감에 효과적이었으며, 이 는 신선편이 둥근마 세척에서 열수가 상온수보다 유의적으 로 낮은 세균수를 나타내었다고 보고한 연구결과와 같았다 (Seong 등, 2017). 특히, $50^{\circ} \mathrm{C}$ 열수 세척구(HWT-50 ${ }^{\circ} \mathrm{C}$ )는 모든 처리구 중에서 일반세균수 저감에 가장 큰 효과를 나타내 었으며, 반대로 $50^{\circ} \mathrm{C}$ 열수 마이크로버블 병용 세척구 $\left(\mathrm{HWT}+\mathrm{MB}-50^{\circ} \mathrm{C}\right)$ 는 $4.8 \pm 0.2 \log \mathrm{CFU} / \mathrm{g}$ 으로 상대적으로 높 은 일반세균수를 보였다. Iizuka 등(2016)은 오일이 묻은 기기표면을 마이크로버블수로 세척한 결과, 마이크로버블 은 오일의 표면을 둘러싼 후 결합하여, 표면으로부터 오일 을 분리하여 세척하였다고 보고하였다. 이와 같이 마이크 로버블이 절단 양상추의 표면을 감싸 $50^{\circ} \mathrm{C}$ 열수가 절단 양상 추에 끼치는 균감소효과를 낮추며, 이에 의해 열수 마이크 로버블 병용 세척구(HWT+MB)가 열수 세척구(HWT)에 비 해 미생물 감균효과가 낮은 것으로 판단된다. Hong 등 (2004)에 따르면, 박피양파를 $50-80^{\circ} \mathrm{C}$ 의 조건으로 세척하 였을 경우, $80^{\circ} \mathrm{C}$ 세척구는 $50^{\circ} \mathrm{C}$ 세척구에 비해 세척초기 중온미생물과 저온미생물을 약 $1 \log \mathrm{CFU} / \mathrm{g}$ 감소시켰다고 보고하였으나, 저장 21 일차의 부패율은 $50^{\circ} \mathrm{C}$ 세척구가 약 $20 \%$ 인 것에 비해 $80^{\circ} \mathrm{C}$ 세척구는 약 $80 \%$ 를 나타내었다. 이와 같이 열수 세척구(HWT)는 미생물 감균에는 효과적이나, 저장기간에 따른 품질변화에는 효과적이지 않았다. 본 연구 결과(Fig. 1)에서도 $50^{\circ} \mathrm{C}$ 열수 세척구(HWT- $\left.50^{\circ} \mathrm{C}\right)$ 의 경우 저장 2 일차의 부패율이 약 $45 \%$ 인 반면, $50{ }^{\circ} \mathrm{C}$ 열수 마이크로 버블 병용 세척구 $\left(\mathrm{HWT}+\mathrm{MB}-50^{\circ} \mathrm{C}\right)$ 는 약 $5 \%$ 밖에 되지 않아, 열수 마이크로버블 병용 세척구 $(\mathrm{HWT}+\mathrm{MB})$ 가 열수 세척구 (HWT)에 비해 감균효과는 다소 낮지만, 저장 기간 중의 선도 유지에는 효과적으로 나타났다.

\section{세척수 종류에 따른 절단 양상추의 진균류 변화}

세척수별 절단 양상추의 진균류 변화를 측정한 결과는 Table 2에 나타내었다. 무세척구(NT)는 수도수 세척구 (Tap)와 마이크로버블 세척구(MB)와 유의적인 차이를 나 타내지 않았으며, 이는 양상추의 세척 전후 진균류는 유의 


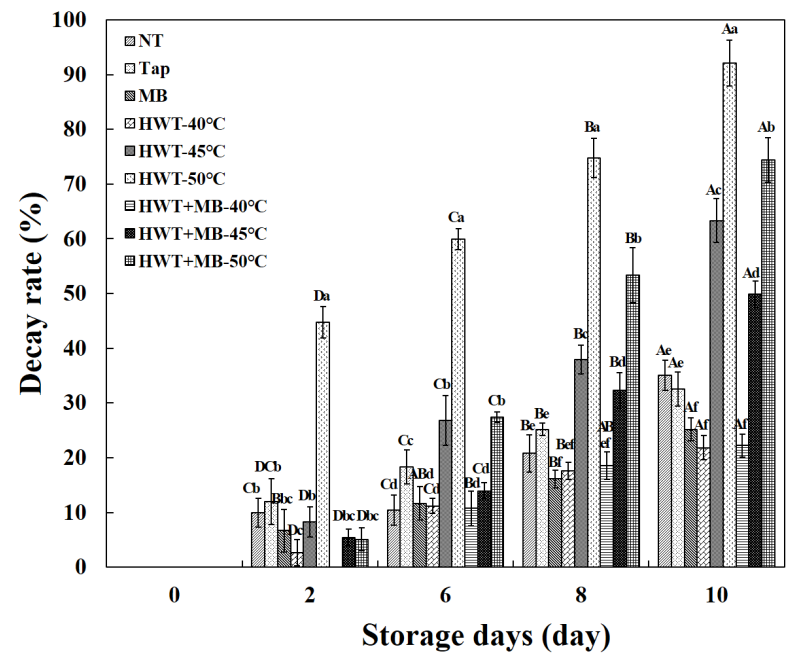

Fig. 1. Decay rate of sliced lettuce stored at $10^{\circ} \mathrm{C}$ for 10 days. ${ }^{1)} \mathrm{NT}$, not treatment; Tap, tap water; MB, microbubble water; HWT, hot water; HWT $+\mathrm{MB}$, microbubble and hot water; Washing time = 1 min.

${ }^{2)}$ Different upper case letters on the bars indicate significantly differences $(\mathrm{p}<0.05)$ depending on the storage period by Duncan's multiple range test.

${ }^{3)}$ Different lower case letters on the bars indicate significantly differences $(\mathrm{p}<0.05)$ depending on the washing conditions by Duncan's multiple range test.

Table 2. Changes in fungi of sliced lettuce washed with various washing conditions (Unit: $\log \mathrm{CFU} / \mathrm{g}$ )

\begin{tabular}{|c|c|c|}
\hline \multicolumn{2}{|c|}{ Treatment $^{1)}$} & Fungi \\
\hline \multicolumn{2}{|c|}{ NT } & $2.3 \pm 0.1^{2 \mathrm{~b} b 3}$ \\
\hline \multicolumn{2}{|c|}{ Tap } & $2.2 \pm 0.3^{\mathrm{b}}$ \\
\hline \multicolumn{2}{|c|}{ MB } & $2.5 \pm 0.2^{b}$ \\
\hline \multirow{3}{*}{ HWT } & $40^{\circ} \mathrm{C}$ & $1.9 \pm 0.1^{\mathrm{b}}$ \\
\hline & $45^{\circ} \mathrm{C}$ & $3.3 \pm 0.0^{\mathrm{d}}$ \\
\hline & $50^{\circ} \mathrm{C}$ & $1.0 \pm 0.0^{\mathrm{a}}$ \\
\hline \multirow{3}{*}{$\mathrm{HWT}+\mathrm{MB}$} & $40^{\circ} \mathrm{C}$ & $2.2 \pm 0.2^{\mathrm{b}}$ \\
\hline & $45^{\circ} \mathrm{C}$ & $1.9 \pm 0.1^{\mathrm{b}}$ \\
\hline & $50^{\circ} \mathrm{C}$ & $3.5 \pm 0.2^{\mathrm{d}}$ \\
\hline
\end{tabular}

${ }^{1)} \mathrm{NT}$, not treatment; Tap, tap water; MB, microbubble water; HWT, hot water; $\mathrm{HWT}+\mathrm{MB}$, microbubble and hot water; Washing time = $1 \mathrm{~min}$.

${ }^{2)}$ Value are mean $\pm \operatorname{SD}(\mathrm{n}=3)$.

${ }^{3)}$ Means with different letters are significantly different $(\mathrm{p}<0.05)$ by Duncan's multiple range test.

차가 없었다는 Koseki 등(2001)의 연구결과와 같았다. 진 균류 감균에 가장 큰 효과를 나타낸 처리구는 $1.0 \pm 0.0 \mathrm{log}$ $\mathrm{CFU} / \mathrm{g}$ 을 나타낸 $50^{\circ} \mathrm{C}$ 열수 세척구 $\left(\mathrm{HWT}-50^{\circ} \mathrm{C}\right)$ 였으며, Park 등(2016)의 연구에서도 오존을 단일 처리한 것보다
열수와 병용 처리한 것이 진균류 저감에 효과적이었다고 보고하였다. 반면 $50^{\circ} \mathrm{C}$ 열수와 마이크로버블 병용 세척구 $\left(\mathrm{HWT}+\mathrm{MB}-50^{\circ} \mathrm{C}\right)$ 는 $3.5 \pm 0.2 \log \mathrm{CFU} / \mathrm{g}$ 으로 진균류의 수가 높게 나타났다. 이는 일반세균 결과와 같이 $50^{\circ} \mathrm{C}$ 의 열수가 마이크로버블수로 인해 절단 양상추에 직접적인 영향을 주지 못하여 진균류 감균에 효과를 나타내지 못한 것으로 판단된다. 일반적으로 채소류와 과실류에서의 진균류는 약 $3 \log \mathrm{CFU} / \mathrm{g}$ 정도 검출되며(Sakai, 1995), 본 연구 결과에 서 대부분의 세척 조건에서 진균류는 약 2-3 $\log \mathrm{CFU} / \mathrm{g}$ 으로 유의차가 나타나지 않았다. $\operatorname{Kim}$ 등(2010)의 연구에서 손세척, 고압세척, 상압세척시 진균류는 세척방법에 따른 유의차가 없었다고 보고하고, 본 연구에서도 세척 방법에 따른 원물의 진균류 감소에는 효과가 없었으므로, 초기 진균류를 효과적으로 제어할 수 있는 처리 기술의 개발이 필요하다고 판단된다.

\section{세척수 종류에 따른 절단 양상추의 대장균군 변화}

절단 양상추의 대장균군은 2.8-3.9 $\log \mathrm{CFU} / \mathrm{g}$ 의 범위로 나타났으며, 결과는 Table 3 과 같다. $50^{\circ} \mathrm{C}$ 열수 세척구 (HWT $-50^{\circ} \mathrm{C}$ )에서 $1.5 \pm 0.0 \log \mathrm{CFU} / \mathrm{g}$ 으로 가장 큰 저감효과 를 나타내었으며, 이는 차염소산으로 세척한 경우 저감되 는 효과와 비슷하며, $5 \mathrm{ppm}$ 의 오존으로 세척한 경우보다 더 효과적이었다(Koseki 등, 2001). 일반적으로 과채류의 대장균군은 3-5 $\log \mathrm{CFU} / \mathrm{g}$ 으로(Sakai, 1995), $45^{\circ} \mathrm{C}$ 열수 처리구 $\left(\mathrm{HWT}-45^{\circ} \mathrm{C}\right)$ 와 $50^{\circ} \mathrm{C}$ 열수 마이크로버블 병용 세척 구 $\left(\mathrm{HWT}+\mathrm{MB} 50^{\circ} \mathrm{C}\right)$ 를 제외한 대부분의 처리구는 $3 \mathrm{log}$

Table 3. Changes in coliform of sliced lettuce washed with various washing conditions

(Unit : $\log \mathrm{CFU} / \mathrm{g}$ )

\begin{tabular}{|c|c|c|}
\hline \multicolumn{2}{|c|}{ Treatment ${ }^{1)}$} & Coliform \\
\hline \multicolumn{2}{|c|}{ NT } & $2.8 \pm 0.4^{2 \mathrm{~b} 3)}$ \\
\hline \multicolumn{2}{|c|}{ Tap } & $3.3 \pm 0.2^{b}$ \\
\hline \multicolumn{2}{|c|}{$\mathrm{MB}$} & $3.3 \pm 0.1^{\mathrm{b}}$ \\
\hline \multirow{3}{*}{ HWT } & $40^{\circ} \mathrm{C}$ & $3.0 \pm 0.2^{\mathrm{b}}$ \\
\hline & $45^{\circ} \mathrm{C}$ & $3.9 \pm 0.0^{\mathrm{c}}$ \\
\hline & $50^{\circ} \mathrm{C}$ & $1.5 \pm 0.0^{\mathrm{a}}$ \\
\hline \multirow{3}{*}{$\mathrm{HWT}+\mathrm{MB}$} & $40^{\circ} \mathrm{C}$ & $3.0 \pm 0.2^{\mathrm{b}}$ \\
\hline & $45^{\circ} \mathrm{C}$ & $3.2 \pm 0.2^{\mathrm{b}}$ \\
\hline & $50^{\circ} \mathrm{C}$ & $3.8 \pm 0.1^{\mathrm{c}}$ \\
\hline
\end{tabular}

${ }^{1)} \mathrm{NT}$, not treatment; Tap, tap water; MB, microbubble water; HWT, hot water; $\mathrm{HWT}+\mathrm{MB}$, microbubble and hot water; Washing time = 1 min.

${ }^{2)}$ Value are mean \pm SD $(n=3)$.

${ }^{3)}$ Means with different letters are significantly different $(\mathrm{p}<0.05)$ by Duncan's multiple range test. 
$\mathrm{CFU} / \mathrm{g}$ 을 나타내어 무세척구와 세척구의 유의차가 나타나 지 않았다. Lee 등(2009)은 세척방법에 따른 상추의 초기 미생물수는 유의적인 차이가 없었지만, 저장기간에 따른 미생물의 증식 속도는 마이크로버블수 세척구에서 가장
느리게 나타났다고 보고하였다. Lee 등(2016)의 연구 결과 에서도 세척 직후 처리구간의 유의차가 거의 없었으나, 저장 기간에 따라 무세척구나 수도수세척구에 비해 오존, 마이크로버블 병용처리구가 미생물 증식 속도가 느리다

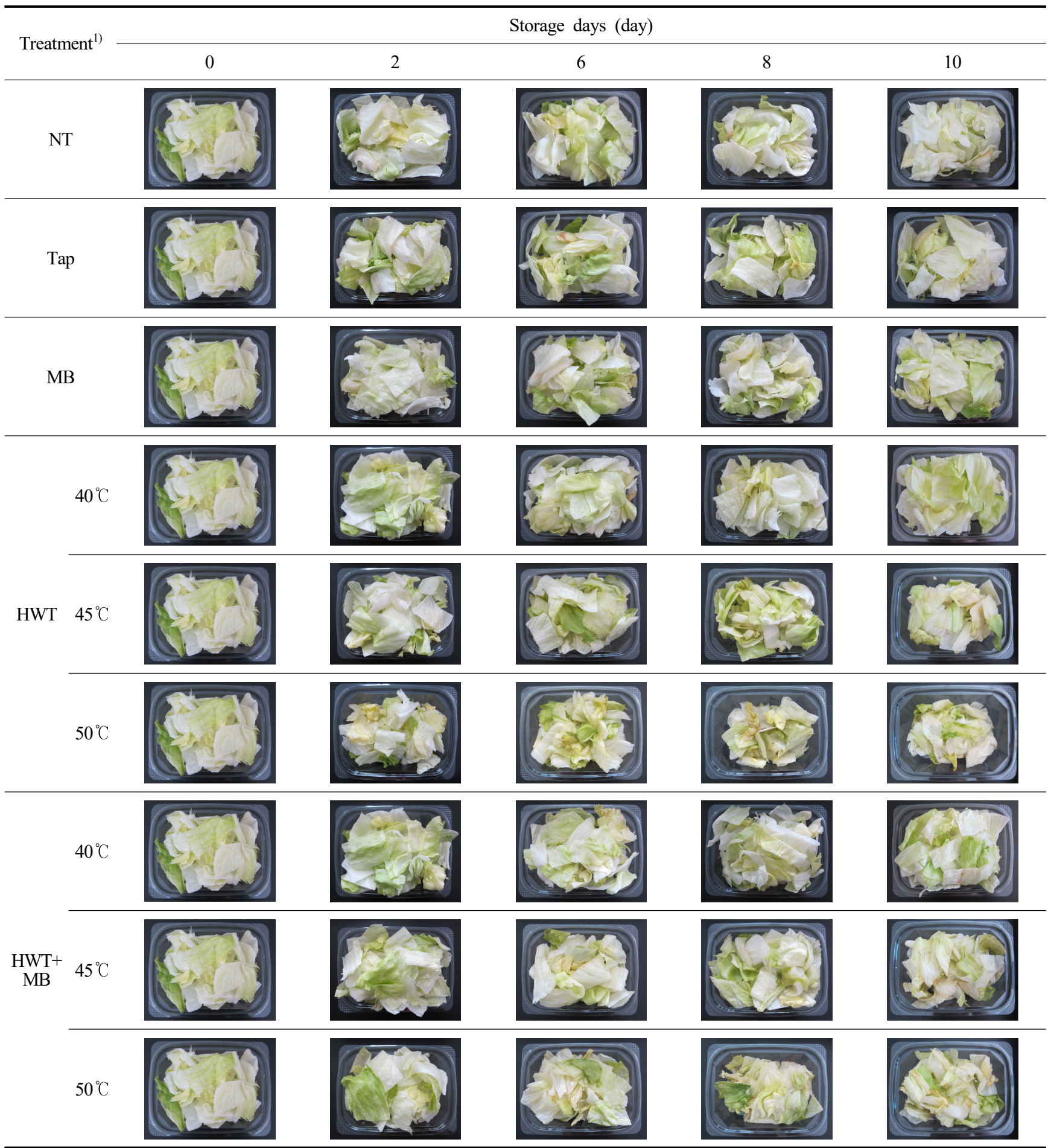

Fig. 2. Changes in appearance quality of sliced lettuce stored at $10^{\circ} \mathrm{C}$ for 10 days.

${ }^{1)} \mathrm{NT}$, not treatment; Tap, tap water; MB, microbubble water; HWT, hot water; HWT $+\mathrm{MB}$, microbubble and hot water; Washing time $=1$ min. 
고 보고하였다. 본 연구 결과에서도 세척 직후 절단 양상추 의 대장균군은 유의적인 차이가 나타나지 않았지만, 저장 중의 미생물학적 품질 변화에서는 열수와 마이크로버블 수의 효과가 나타날 가능성이 있으므로 저장 기간에 따른 부패율 측정을 통해 세척 방법에 따른 양상추의 품질 변화 를 확인하였다.

\section{저장 기간에 따른 절단 양상추의 품질 변화}

세척 조건에 따라 세척한 후 $10^{\circ} \mathrm{C}$ 저장고에서 10 일간 저장 하면서 부패율의 변화를 살펴본 결과는 Fig. 1 및 Fig. 2 와 같다. 세척 직후 절단 양상추의 미생물학적 변화에서는 마이크로버블 세척구(MB)와 열수 마이크로버블 병용 세 척구 $(\mathrm{HWT}+\mathrm{MB})$ 의 감균효과가 크게 나타나지 않았지만, 저장기간에 따른 품질 변화는 효과적으로 나타났다. 무세 척구(NT)와 수도수 세척구(Tap)는 저장 2 일차부터 약 $10 \%$ 의 부패율을 보이며 비슷한 증가 속도를 보였으며, 저장 10 일차에 약 $32-35 \%$ 정도 부패하였다. 반면 마이크로버 블 세척구(MB)는 무세척구(NT)와 수도수 세척구(Tap)에 비해 부패 속도가 약 $35 \%$ 가량 감속되었다. 저장기간 동안 마이크로버블 세척구(MB)는 수도수 세척구(Tap)에 비해 갈변이 적으며, 조직이 단단하여 우수한 품질 상태로 유지 되었다. 이는 상추를 세척한 후 9일간 저장한 결과 마이크 로버블 세척구가 관능적으로 가장 우수하게 유지되었다 고 보고한 Lee 등(2009)의 결과와 같았다. Kim 등(2012)은 열처리를 병용한 처리구에서 조직손상의 간접 지표인 전 기전도도가 높게 나타나 열처리에 의한 품질 저하현상에 대해 보고하였다. 본 연구 결과에서도 열수 세척구(HWT, $\mathrm{HWT}+\mathrm{MB})$ 는 상온 세척구(Tap, MB)에 비해 부패율이 높 게 나타나 고온의 열수 세척은 저장 기간 중 품질 변화에 영향이 있음을 확인하였다. 전반적으로 같은 열수 세척 온도에서의 부패율은 열수 세척구(HWT)보다 열수 마이 크로버블 병용 세척구(HWT $+\mathrm{MB})$ 에서 낮게 나타났으며, 이는 마이크로버블이 열수의 직접적인 열전달을 일부 차 단하였기 때문에 열에 의한 절단 양상추의 조직손상이 적었기 때문으로 판단된다. 특히 $50^{\circ} \mathrm{C}$ 열수 세척구 $\left(\mathrm{HWT}-50^{\circ} \mathrm{C}\right)$ 는 저장 2 일차에 약 $45 \%$ 의 부패율을 나타내 상품성을 소실한 반면, $50^{\circ} \mathrm{C}$ 열수 마이크로버블 병용 세척 구 $\left(\mathrm{HWT}+\mathrm{MB}-50^{\circ} \mathrm{C}\right)$ 는 같은 $50^{\circ} \mathrm{C}$ 의 열수를 가하였음에도 불구하고, 저장 2 일차에 $5 \%$ 의 부패율을 나타내었다. Inatsu 등(2011)의 연구에서도 오존-마이크로버블 병용 세 척구가 오존 단일 처리구에 비해 관능적으로 우수하다고 보고하였다. Yucel Sengun과 Kendirci(2018)은 절단 양상추 를 오존수로 세척한 결과, 미생물학적 품질평가는 유의적 인 차이가 없었으나, 관능적 평가에서는 세척온도가 낮은 처리구에서 품질 변화율이 적었다고 보고하였다. 본 연구 에서는 미생물학적 품질평가의 경우 $50^{\circ} \mathrm{C}$ 의 고온 세척이
효과적이었으나, 저장 기간에 따른 부패율에서는 $50^{\circ} \mathrm{C}$ 세 척구 $\left(\mathrm{HWT}-50^{\circ} \mathrm{C}, \mathrm{HWT}+\mathrm{MB}-50^{\circ} \mathrm{C}\right)$ 보다는 $40^{\circ} \mathrm{C}$ 세척구 $\left(\mathrm{HWT} 40^{\circ} \mathrm{C}, \mathrm{HWT}+\mathrm{MB}-40^{\circ} \mathrm{C}\right.$ )가 낮게 나타났으며, $40^{\circ} \mathrm{C}$ 세 척구는 상온의 마이크로버블 세척구 $(\mathrm{MB})$ 와 비슷한 결과 를 나타내었다. Fig. 2의 결과와 같이 육안으로 보이는 갈 변, 부피감 등의 특성에서도 같은 결과를 나타내었다. 결과 적으로 마이크로버블 단독처리, 열수와의 병용처리는 갈 변과 수분손실로 인한 시듦 현상을 억제함으로써 품질 유지에 영향을 주는 것으로 판단되며, 추후 저장기간에 따른 절단 양상추의 미생물학적 품질평가에 대한 후속 연구가 필요하다.

\section{요 약}

$40^{\circ} \mathrm{C}$ 열수 마이크로버블 병용 세척구 $\left(\mathrm{HWT}+\mathrm{MB}-40^{\circ} \mathrm{C}\right)$ 의 미생물 저감효과는 $50^{\circ} \mathrm{C}$ 열수 세척구 $\left(\mathrm{HWT}-50^{\circ} \mathrm{C}\right)$ 보다 낮았으나, 부패율의 경우 저장 2 일차까지 $0 \%$ 를 유지하였 고, 저장 6 일차에는 $11 \%$ 로 가장 낮은 수치를 보여주었다. 마이크로버블 세척구는 저장 2 일차 $7 \%$ 의 부패율을 나타 내었으나, 10 일간의 저장 기간 동안 부패율이 $30 \%$ 미만으 로 나타났고, 이는 $40^{\circ} \mathrm{C}$ 열수 마이크로버블 병용 세척구 $\left(\mathrm{HWT}+\mathrm{MB}-40^{\circ} \mathrm{C}\right)$ 와 유사한 경향으로 나타나, 마이크로버 블 처리는 저장 중 양상추의 품질 유지를 위한 효과적인 처리 기술이라고 판단된다. 절단 양상추와 같은 신선편이 제품의 유통기한은 제품 생산 후 3-4일 이내이므로, 세척 후 저장기간 동안 품질이 우수하게 유지된 마이크로버블 세척구와 $40^{\circ} \mathrm{C}$ 열수 마이크로버블 병용 세척구(HWT+ $\left.\mathrm{MB}-40^{\circ} \mathrm{C}\right)$ 는 절단 양상추의 저장 중 품질향상을 위한 적합 한 처리방법이며, 친환경적인 세척수로서의 마이크로버 블수의 가능성을 확인하였다. 결과적으로 마이크로버블 의 사용은 양상추의 저장 중 품질 유지에 효과가 있으며, 열수와 마이크로버블의 병용 처리는 열수 단독 처리에 비해서 감균효과가 다소 낮지만, 온도 조건에 따라 품질 유지 효과에는 차이를 보였다. 마이크로버블과 열수 마이 크로버블 병용처리는 절단 양상추의 품질 유지에 효과적 일 것으로 판단되며, 친환경적인 세척 방법으로 수확 후 세척 기술에 유용하게 적용할 수 있을 것으로 생각된다.

\section{감사의 글}

본 논문은 한국식품연구원의 지원을 받아 수행된 연구 (E0187301-03) 결과로 이에 감사드립니다.

\section{Conflict of interests}

The authors declare no potential conflict of interest. 


\section{ORCID}

Hyo Jin Kim https://orcid.org/0000-0003-4788-8388

Minseon Koo https://orcid.org/0000-0003-3718-6120

\section{참고문헌}

Ahvenainen R. New approaches in improving the shelf life of minimally processed fruit and vegetables. Trends Food Sci Technol, 7, 179-187 (1996)

Allende A, Artes F. UV-C radiation as a novel technique for keeping quality of fresh processed 'Lollo Rosso' lettuce. Food Res Int, 36, 739-746 (2003)

Cho MH, Bae EK, Ha SD, Park YS, Mok CK, Hong KP, Kim SP, Park JY. Evaluation of dry rehydratable film method for enumeration of microorganisms in meat, dairy and fishery products. Korean J Food Sci Technol, 37, 294-300 (2005)

Choi DJ, Lee YJ, Kim YK, Kim MH, Choi SR, Cha HS, Youn AR. Effect of washing methods on the quality of freshly cut sliced Deodeok (Codonopsis lanceolata) during storage. Korean J Food Presrv, 20, 751-759 (2013)

Gemma OO, Alejandra RG, Gonzalez LA, Varela P, Soliva-Fortuny R, Hernando MIH. Recent approaches using chemical treatments to preserve quality of fresh-cut fruit: A review. Postharvest Biol Technol, 57, 139-148 (2010)

Hong SI, Lee HH, Son SM, Kim DM. Effect of hot water treatment on storage quality of minimally processed onion. Korean J Food Sci Technol, 32, 239-245 (2004)

Huxsoll CC, Bolin HR. Processing and distribution alternatives for minimally processed fruits and vegetables. Food Technol, 43, 124-128 (1989)

lizuka A, Iwata W, Shibatam E, Nakamura T. Phyical washing method for press oil removal from side surfaces using microbubbles under ultrasonic irradiation. Ind Eng Chem Res, 55, 10782-10787 (2016)

Inatsu Y, Kitagawa T, Nakamura N, Kawasaki S, Nei D, Bari ML, Kawamoto S. Effectiveness of stable ozone microbubble water on reducing bacteria on the surface of selected leafy vegetables. Food Sci Technol Res, 17, 479-485 (2011)

Izumi $\mathrm{H}$. Electrolyzed water as a disinfectant for fresh-cut vegetables. J Food Sci, 64, 536-539 (1999)

KFDA. Food Code. Korea Food and Drug Administration, Cheongju, Korea (2017)
Kim HS, Kim EJ, Choi JH, Hong SI, Jeong MC, Kim DM. Reduction of microbial populations on the surface of fresh ginseng by various washing treatments. Korean J Food Preserv, 17, 405-409 (2010)

Kim JG, Nimitkeatkai H, Choi JW, Lee SG. The effects of calcinated calcium solution washing and heat treatment on the storage quality and microbial growth of fresh-cut broccoli. J Bio-Env Con, 21, 411-418 (2012)

Koseki S, Yoshida K, Isobe S, Itoh K. Decontamination of lettuce using acidic electrolyzed water. J Food Prot, 64, 652-658 (2001)

Lamikanra O. Fresh-Cut Fruits and Vegetables. CRC Press, New York, USA, p 187-222 (1981)

Lee SA, Youn AR, Kwon KH, Kim BS, Kim SH, Cha HS. Washing effect of micro-bubbles and changes in quality of lettuce (Lactuca sativa L.) during Storage. Korean J Food Preserv, 16, 321-326 (2009)

Lee UK, Joo SH, Klopfenstein NB, Kim MS. Efficacy of washing treatments in the reduction of post-harvest decay of chestnuts (Castanea crenata 'Tsukuba') during storage. Can J Plant Sci, 96, 1-5 (2016)

Lee WJ, Lee CH, Yoo JY, Kim KY, Jang KI. Sterilization efficacy of washing method using based on microbubbles and electrolyzed water on various vegetables. J Korean Soc Food Sci Nutr, 40, 912-917 (2011)

Li Y, Brackett RE, Chen J, Beuchat LR. Survival and growth of Escherichia coli O157:H7 inoculated onto cut lettuce before or after heating in chlorinated water, followed by storage at $5^{\circ} \mathrm{C}$ or $15^{\circ} \mathrm{C}$. J Food Prot, 64, 305-309 (2001)

Liu S, Oshita S, Kawabata S, Makino Y, Yoshimoto T. Identification of ROS produced by nanobubbles and their positive and negative effects on vegetable seed germination. Langmuir, 32, 11295-11302 (2016)

Martin-Diana AB, Rico D, Barry-Ryan C, Frias JM, Mulcahy J, Henehan GT. Comparison of calcium lactate with chlorine as a washing treatment for fresh-cut lettuce and carrots: Quality and nutritional parameters. J Sci Food Agric, 85, 2260-2268 (2005)

Park KJ. Development of Reduction technologies for norovirus and food-borne pathogens in agricultural and fishery fresh produces. Final Report of KFRI, TRKO 201400030018 (2013)

Park KM, Lee JY, Min SR, Jeong MC, Koo MS. Quality and shelf life of sliced root of Platychdon grandiflorum treated by ozon-microbubble-heat shock. Korean J Food Preserv, 23, 605-613 (2016) 
Ricoa D, Martin-Diana AB, Baratb JM, Barry-Ryan C. Extending and measuring the quality of fresh-cut fruit and vegetables: A review. Trends Food Sci Technol, 18, 373-386 (2007)

Sakai S. Application and development of electrolyzedoxidizing water. Food Ind, 30, 35-43 (1995)

Seong BJ, Kim SI, Jee MG, Kim SD, Kwon AR, Kim HH, Lee KS. Quality characteristics of fresh-cut Dioscorea bulbifera treated under various blanching conditions prior to vacuum-packaging during storage. Korean J Food Preserv, 24, 565-575 (2017)

Van Haute S, Sampers I, Holvoet K, Uyttendaelea M.
Physicochemical quality and chemical safety of chlorine as a reconditioning agent and wash water disinfectant for fresh-cut lettuce washing. Appl Environ Microbiol, 79, 2850-2861 (2013)

Wang H, Feng H, Luo Y. Microbial reduction and storage quality of fresh-cut cilantro washed with acidic electrolyzed water and aqueous ozone. Food Res Int, 37, 949-956 (2004)

YuceL Sengun I, Kendirci P. Potential of ozonated water at different temperatures to improve safety and shelf-life of fresh cut lettuce. Ozone Sci Eng, 40, 216-227 (2018) 